В представленной статье рассматривается эволюция потребительства в восточногерманском обществе в контексте проведения Лейпцигских торговых ярмарок в 50-е гг. XX в. Начало 50-х гг. характеризуются восстановлением национальной экономики, и перед партийным руководством возникают новые вызовы: июньские события 1953 г. показали руководству необходимость проведения социальных реформ по улучшению материального состояния населения с целью упрочения своих позиций в государстве. Лейпцигская ярмарка в свою очередь стала своеобразной витриной прогресса народного хозяйства ГДР, призванной сформировать у населения образ развитого производства товаров и услуг. Анализ потребительской ситуации в ГДР проводится с учетом экономических, идеологических и социальных условий проведения руководством СЕПГ Лейпцигской ярмарки. В статье также подробно рассмотрена работа различных ведомств и министерств в организации ярмарки и роль Лейпцигской ярмарки, обозначенная руководством, в улучшении потребительского благополучия населения.

В процессе работы над данной темой исследования использовался широкий круг источников, включающий немецкие и американские исследования по истории по- требительства в ГДР, а также донесения ЦРУ по проведению Лейпцигской ярмарки.

В заключении авторы приходят к выводу, что, несмотря на осознание руководством СЕПГ важности проведения социальных реформ по улучшению благосостояния населения, Лейпцигская ярмарка служила катализатором несостоятельности восточногерманской плановой экономики в обеспечении необходимого роста товаров и услуг: одним из главных препятствий являлось нарушение традиционной системы спроса и предложения, а созданные руководством каналы обратной связи с населением не обеспечили необходимую связь между производителем и потребителем. Однако из исследования данной тематики становится очевидно, население ГДР оказывало влияние на проведение СЕПГ социальной политики, хоть и не в значительной степени, что побудило руководство ГДР к концу 50-х гг. XX в. сделать акцент на работе с общественностью посредством агитационной и рекламной деятельности отделения прессы и рекламного отделения Лейпцигской ярмарки.

Ключевые слова: Лейпцигская ярмарка, потребление, СЕПГ, внешняя торговля, плановая экономика, легитимация ГДР.

\title{
LEIPZIG TRADE FAIR IN 1950s: BETWEEN DECISION-MAKING AND CONSUMPTION
}

Evolution of consumerism in the East German society in the context of holding the Leipzig Trade Fair in 1950s is considered in the article. The beginning of 1950 s is characterized by restoration of national economy and the party leadership faced new challenges: the June events of 1953 showed the leadership the necessity of carrying out social reforms on improving the material welfare of the population in order to strengthen its positions in the state. The Leipzig Fair was in its turn a showcase of progress of people's economy of the GDR designed to form an image of developed production of goods and services to the population. Analysis of consuming situation in the GDR is made within economic, ideological and social conditions of holding the Leipzig Fair by East German leadership. The activity of various institutions and ministries in the organization of the Fair and the role of the Leipzig Fair in improving consumering welfare in the state designed by the leadership are considered in the article.

In the process of investigation, the authors use a broad range of sources including German and American research- es on the history of consumption in the GDR and reports of the CIA on holding the Leipzig Fair.

The authors come to conclusion that despite the SED leadership realized the importance of carrying out social reforms on improving welfare of the population, the Leipzig Fair served as a catalyst of inconsistency of East German planned economy as regards providing necessary growth of goods and services. The disruption of the traditional demand and supply system was one of the main obstacles, and feedback channels with the population created by the leadership did not result in a necessary link between the producer and the consumer. However, it becomes clear from investigation of the given topic that the population made an impact on carrying out social policy by the SED, albeit to a minor extent. It made the GDR leadership focus on public relation activity by means of agitation and advertising activity of the press office and advertising office of the Leipzig Fair by the end of 1950 s.

Key words: Leipzig Trade Fair, consumption, SED, foreign trade, planned economy, legitimacy of the GDR. 
After World War II Germany still remained in ruins. The war led the country to total economic starvation. The currency was no longer of any value, there was an acute shortage of essential goods and the population aspired to forget sooner the terrors of war, of Nazism and enduring hardships. After Germany's division into two separate countries, the young East German state had to solve the problems of economic recovery and legitimacy of socialist regime both in the world and within the State. In the escalating cold war the confrontation of Western capitalist and Eastern socialist political blocs penetrated in all spheres of everyday life of a common East German citizen: education, labor, family, leisure and, of course, consumption. Both West and East Germany sought to get rid of the traces of war, to "overcome their own past". The possibility of the system to provide for the consuming needs of the population became one of the most important rates of sustainability of political system. And the leadership of the SED (Socialist Unity Party of Germany) looked for that possibility.

A great amount of details about the consumption in the GDR is represented in numerous German and American studies of the GDR in the context of a rather new field of historic science called Konsumgeschichte (in German) or the history of consumption. This field of history is greatly affected by humanization of historic science since 1950-1960s and it draws its attention to various aspects of conditions of consumption and a development of consuming culture in a society. This new historic branch is connected to economic and social history (history of retail trade, of agriculture, of standard of life), cultural history and Alltagsgeschichte, or history of everyday life (history of nutrition, of goods, of material culture, of festivals) and to history of art (design, advertising) [12]. The investigation of consumption in the GDR became popular since the end of 1990s when researches got an access to various archives of the GDR. It is no secret that the GDR as any socialist state confirmed since the very formation of the state the conception of "dictatorship over needs" that supposed total political control over needs of population [1, p.748]. However, the events of June in 1953 showed the SED leadership a necessity to meet people's demands in order to legitimate their regime and since then the improvement of standard of life amidst the population made part of East German plan. Regardless there are many investigations about the development of consumption in East Germany the processes characterizing shifting from Stalinist autarchic economic model that excluded any possibilities of focusing on conditions of consumption to programs focusing on providing for new consumer future in 1950s still require more research. A special interest presents the role of Leipzig Fair in these processes, as it became a significant part of economic, political and social life of the GDR since the formation of the state.

This article is to answer the main question: "What role did the Leipzig Trade Fair play in improving conditions of consumption of the main population of the GDR by the party leadership?". Before giving an an- swer to this question it is necessary to indicate the role of the Leipzig Fair in the life of East Germany. The status of this event is ideally indicated in the East German guide "Meet the GDR":

"The Leipzig Fair is of great importance for GDR foreign trade. It is held twice a year and its character of universality with 60 branch groups corresponds to its special nature as intermediary between East and West. The Leipzig Fair has continually gained in popularity since the Second World War. This is shown by the number of countries participating, the exhibition area, the volume of trade concluded and the number of visitors and exhibitors. This centre of world trade is a meeting-place for the socialist, capitalist and emergent states, where they can practise peaceful cooperation without discrimination for their mutual benefit $[7$, p. 63]"

Such metaphors as "intermediary between East and West", "centre of world trade" completely reflect the role of the fair defined by the SED as a crossroad of two competing worlds: capitalist West and socialist East, and as the most important trading platform of the GDR where numerous trade agreements could be concluded both with socialist and capitalist bloc countries. Even since the Middle Ages Leipzig stood at the intersection of two important trade routes "Via Regia" from Rhine to Silesia and "Via imperii" from Italy to the Baltic Sea. Moreover, over the centuries the city still remains the capital of European trade, hundreds of producers and trade organizations conclude trade bargains with each other and pavilions and stands are decorated with numerous commodities aimed at marking the revival of new socialist Germany.

One can notice from the given description that the Leipzig Fair was a place of interaction of East and West. However, this interaction was not limited only to economic and cultural aspects. Since the first afterwar "fair of peace" in 1946 SMAD and then the GDR leadership aspired to show the Western world rapid progress of East German socialist economy and its superiority over capitalist economy. Especially actual this ideological strive became after gradual normalization of economic situation in the GDR since the beginning of 1950s. The GDR leadership began using the Leipzig Fair in order to show scientific and technological progress and its superiority comparing of course, to capitalist states. So, originally trade fair became an ideological tool of forming an image of success of planned economy. But why was it so essential for the GDR to prove its superiority? The main reason is to justify the legitimacy of young socialist state bypassing so called Halstein doctrine of West Germany that supposed breaking all diplomatic ties the GDR so that no one admitted the legality of the "communist" regime.

As it was mentioned above, the economic development of the GDR showed since its first years significant backlog in economic growth comparing to the FRG. It had a severe shortage of many raw materials as cotton, rubber, aluminum, steel, natural wood etc. The state needed necessary imports and, in this regard, the Leipzig Trade Fair really became the 
place of tough trade. The party leadership aspired to combine both objectives and there is some statistics showing that the SED did much to promote making trade agreements and increase of foreign exhibitors and visitors. Thus, Pryor Frederic in his study of the communist foreign trade system marks that the value of export contracts concluded on the Leipzig Fair increased from 1957 to 1959 from 2661 to 4054 million DMs and the number of import contracts increased from 593 to 1479 million DMs, respectively [10, $p$ 94]. The main trading partner of East Germany was West Germany.

The popularity of the Leipzig Fair also grew. For example, the Fair in 1953 was visited by 538000 people from 52 countries including 8245 from West Germany. In 1954 the number was increased to 673000 people from 56 countries (15500 from West Germany). That made the Leipzig Fair administration find solutions to expand the territory of the Fair so that more exhibitors and visitors could take part in this event. This all showed that the Leipzig Fair gained gradually popularity in 1950s [3].

Now it is important to draw attention to how the Fair was organized, what offices regulated various preparations to it. The main point to be considered is that the holding of the Leipzig fair was a part of East German planned economy that concentrated all economic decision-making around political elites of the GDR. The main directives were issued by the Ministerial Council that functioned under Walter Ulbricht and made all important economic and administrative decisions. There was also governmental commission that was responsible for planning of the Leipzig Fair and could make suggestions to directives of the Ministerial Council. The governmental commission was presented different state institutions including the Ministry of Foreign Affairs, the Ministry of the Interior, the Ministry of Foreign and Domestic Trade and the Ministry of Culture [8, p. 141]. That shows that the Leipzig Fair had a significant value and its holding was centralized in hands of the SED leadership. The main executive responsibilities were carried by Messeamt (the Fair office). The government tried to engage various institutions in order to implement its objectives: to set real trade with Socialist bloc and (what is more important) Western countries, first and foremost with West Germany and to provide for legitimacy of the state by showing superiority of socialist economy that constituted an ideological component of the Fair.

But what about the main population? How would the SED leadership improve conditions of consumption amidst ordinary people? It was considered at the beginning of the article that 1950 s was a period of normalization of East German economy. The supply of food gradually developed and getting necessary food and commodities stopped being a question of survival. However, the GDR unlike other socialist states had its German counterpart presented by capitalist regime and Germany transferred to an ideological arena of capitalist and socialist experiments where it was extremely important for both regimes to prove superiority. But economic backlog became evident since the beginning of 1950 s and the SED couldn't hide the real situation from citizens of the GDR. They observed growing affiliation of goods in the West and empty stores in their country. And the June events of 1953 convinced the leadership in a necessity of improving level of consumption. People began to influence (albeit in small measure) the policy of the GDR. The government made lots of populist promises for better conditions of consumption in the near future. The principle of "dictatorship over needs" gradually changed to "outrunning the West" [6, p.24]. In daily life, however, the changes were scarce: there was no competition among enterprises as they were mostly state-owned, no marketing and advertising of goods as it was regarded as a capitalist phenomenon. East German economy did not boost in conditions of demand or supply and a free competition as in the West, there were no factors boosting socialist economy in conditions of state planning. But the Leipzig Fair was an opportunity to prove the population the consistency of planned economy by showing them the abundance and great variety of exhibited production that was imaged in propaganda as an achievement of all working people. The number of visitors of the fair increased each year and also increased the number of exhibited production and participating countries. Trade agreements of the GDR with western countries were concluded more often. Visitors of the fair had an opportunity to behold "victory of socialism".

People's demands began to grew since the normalization of supply of food and commodities, and in mid-1950s the SED presents conception of modernization of economy and society through "the technological revolution" [6, p.24]. And here the importance of the Leipzig Trade Fair grew: visitors from capitalist countries should witness socialist technological progress. A special tool of forming the image the fair as a "showcase of Germany" was agitation and propaganda activity of SED. Advertising offices and printing houses were involved to print numerous guides of the fair, brochures, leaflets and post stamps with views of Leipzig. Streets during the fair were clean and decorated with huge posters with party slogans everything should create festive atmosphere of the central trade fair. A separate press office of the Leipzig fair was created for public relations work [8, p.138]. Astrid Otto marks that since the end of 1950s a notion "Public Relations" emerges in the lexicon of the government that supposed interaction with the general public. Public relations were implemented by means of the press office of the Leipzig Fair and advertising commission that shot an image film "World Fair Leipzig" in 1959 [8, p. 138]. However, such efforts in making a positive image of the Fair led to a reverse: lots of visitors were assumed that the exhibition stopped being an exhibition literally, it began to remind a political show. Someone also marked tastelessness and clumsiness of agitation activity of corresponding offices.

An agitation and propaganda activity of the SED could not hide real situation on the Fair. Analysis of foreign reports and newspaper articles about the 
Leipzig trade fair in 1950-ies makes adjustments in forming its real image. Thus, a variety of reports about the Leipzig fair in period 1950-55 presented for the CIA contains stable criticism towards production exhibited by the GDR and the fair in whole. According to the data, the presence of non-functioning commodities that were retouched from the outside but could simply miss one or even more details particularly shocked visitors. A lot of commodities were produced in 1941-43. They were called as a joke "Potyomkin villages" [4].

An acute shortage of food during the fair was another problem. One author of a story on the Leipzig fair in 1953 in the newspaper "Le Monde" marks disrupting provision of food of the fair [2]. The author describes in details the situation when many foreign participators and visitors of the fair had to stand on queues of 200 accredited persons hoping to buy some eggs or meat dishes and only $60 \%$ succeeded in gaining them. Finding a lodging during the fair was also a big problem. Western journalist gives following information about this: "The lodging problem is acute. With the hotels filled, all Leipzig rents rooms. The choice is limited. While the foreigners bureau assures you of a "modern room with running water", it is invariably only 4 meters square with no room to move about."

Regardless all efforts of the GDR government to persuade the population by various exhibited production that socialism can guarantee people consuming welfare, citizens saw distinct discrepancy between illusion of welfare created by the government and reality of continuing shortages of goods. Catherine Pence marks in her study of the GDR consuming culture from the example of the Leipzig fair that exhibited commodities not always corresponded needs of the population and if they did, a common person could not afford them. Lots of East German goods observed by citizens were mainly purposed for export and people had little chances to see them on the shelves of stores. The situation was worsened by a fact that East Germans could see face to face consuming superiority of West Germany where the abundance of goods was real instead of SED ephemeral promises for improvement of life conditions in the GDR $[9$, p.35]. That all led to mass criticism of East German planned economy, the population stopped believing in promises of the state. One East German engineer marked in an interview with Western journalist during the Leipzig Fair in 1953: "The situation is constantly worsening and discontent is widespread. The workers are sick of norms and are resisting any increases. No one believes in the sincerity of the new government policy." The journalist then marked in his report that "people appear to have accumulated their resentment over the long winter months to release it at one blow at fair time". He added: "Leipzig may appear to be well kept, well fed, and very pleasant, but the appearance is artificial. After the fair, the city returns to hibernation for another 11 months [2]"

This example shows that the Leipzig Fair did not spread on common life of the population. And the discrepancy between festive illusion of the atmosphere and reality only irritated people. That led to the emergence clandestine black market during the Leipzig Fair. Catherine Pence marks that illicit barter transactions formed an integral part of the fair life. The authorities answered by tightening control over visitors and limiting the number of trade observers at the fair, however, that didn't lead to solving the current situation $[9$, p.40].

Analyzing the reasons of incapacity of the GDR leadership to provide for consuming demands of the population it is extremely important to reveal the influence of the Soviet Union on decision-making of the GDR and its link to the consuming situation in the state because this angle of considering is often underestimated in researches. Since its very formation the GDR as similar republics of the socialist bloc was in the orbit of political and economic influence of the USSR. It would be wrong to assert that the vector of first-years economic development of the GDR was defined by the SED. The GDR as other socialist republics began to copy planned economic policy of the Soviet Union. Stalinist model of economic development proposed concentration of all efforts on building domestic production by implementing directive five-year economic plans. Foreign trade according to Stalin's views presented a threat to economic and political independence of socialist republics, that is why reducing import and investing in heavy industry, chemical production and electricity $[10, p .25]$. The creation of the CMEA proposed economic rapprochement of the socialist bloc countries and making trade contacts with each other. But it became evident later that such a system of economic development was appropriate only for the USSR and the PRC as these countries had a rich system of resources and trade among socialist states had not been fully made that was characterized by common economic problems and common deficit of raw materials $[10, p .31]$. That shows indeed dependence of the GDR setting trade relations with other countries.

However, the economic course set by the Soviet Union led to the disruption of trade mechanisms. Plan character of the economic system and concentration of decision-making capacities in upper circles disrupted the economic balance. Centralization of economy led to its bureaucratization. The system of demand and supply went wrong and the planning commission aspired to compensate it by creation of a complicated branch of subordinate offices specializing on one of the branches of production and trade. Foreign trade was also made on a planned decision-making basis, foreign trade enterprises were allowed to trade with western firms strictly according to directive instructions of the Ministry of foreign and domestic trade. But as a consequence of autarchic policy the relationship between foreign trade enterprises and domestic people's enterprises that could transmit demands on import was broken. And all that made the link between producer and customer quite difficult that erupted into a shortage of necessary goods of consumption and a surplus of unnecessary production that was a result of plan implementation. 
It will be also important to mention that fair and exhibition activity was in the area of interests of the USSR. After an emergence of socialist bloc states Stalin encouraged holding of East European fairs aimed to reflect unity of socialist economy and results of common labor. Literally, since the first afterwar years competing of socialist and capitalist countries on trading arena became fierce. The Leipzig Fair was very important for the Soviet Union as it desired to hold political control over East Germany and show the world supremacy of socialism. Stalin took over control over first Fairs and all decision-making was regulated by SMAD. For example, the directive of 1948 obliged firms to make barter transactions of metals, sheet metal, wire, textile raw materials, etc [5]. But since the Thaw in the USSR the situation began to change: the SED gained control over decision-making (although CMEA countries were obliged to follow single planned economic decisions).

To summarize the considered factors of the impact of the USSR on East German economy one can make following conclusions. Firstly, the Stalinist model of autarchic economy that was copied by the SED was not appropriate for East Germany for many reasons. Unlike the Soviet Union the economy of the GDR wasn't self-sufficient, it lacked important materials and needed foreign trade. Secondly, Soviet model of economic development paid little attention to improvement of consuming conditions of the population and mainly concentrated on the development of heavy industry. East German government soon realized the importance of providing the population for better conditions of consumption but it became complicated as the system of demand and supply went wrong and one of the main reasons why people were discontent of the exhibited production is that feedback channels defining demands of the population were disrupted. So, it becomes clear that the Soviet model of planned economy gave a bad start for economic and consuming development of the GDR.

The authorities of the GDR tried to solve the problems of planned economy. For example, they tried to create feedback channels compensating absence of supply and demand system. One of these channels were common housewives. They had a special mission to inform the Ministry of Economy about the quality of produced household appliances and the SED sent groups of women from the Democratic women's union of Germany to the Leipzig fairs who informed the authorities about the correspondence of exhibited household goods with the population needs and also compared East German production with West German. The party even established organ of the press "Frau von Heute" where reports of women's groups from the fairs were published [ 9 p.38]. It is unclear if these reports influenced making contacts between producer and customer but there's a reason to assume that such channels of informing and expression of people's opinion were just a way to channel criticism of the population about the GDR consuming culture towards direction controlled by the regime.
Having considered different aspects of the Leipzig fair activity in 1950s, we can conclude that the Leipzig fair served as a catalyst for display of a growing gap between the image of welfare in the GDR created by the SED and the real situation. The authorities understood the importance of consuming needs of the population and they used the fair as propaganda tool to make an impression of the state economic development and to reassure the population that the SED leads people to a better consuming future. However, the population realized that the majority of exhibited products would never be sold throughout the country and illicit barter trade took place during the fairs so that people could buy necessary items unavailable in common stores. One of the reasons why the government couldn't meet consuming needs and why the Leipzig Fair only underlined the discrepancy between West and East German conditions of consumption is that the struggle of the GDR with its Western neighbor for the state that can provide its population for better goods and commodities was made on the plane of capitalist value. As Susan Reid marks in her investigation of the Soviet fair and exhibition activity: "in the Khrushchev-era some kind of convergence with the West's symbols and cultural forms began to emerge within legitimate culture" $[11, p .2]$. She connects rapprochement, during the Thaw, with purely capitalist symbols of good life and transition of a socialist citizen "from producer to consumer". This can be surely applied to the Leipzig Fair that reflected all aspirations of the SED leadership to demonstrate the population and the West the affluence of goods. There are sufficient reasons to assume that the political elites of East Germany realized the incapacity of planned economy to compete fire with fire with the West. So, answering the question at the beginning of the article "What role did the Leipzig Trade Fair play in improving conditions of consumption of the main population of the GDR by the party leadership?", we can say that the Fair was more a means of forming a preferable image of welfare of East German economy than a real attempt to improve conditions of consumption of the population as the government didn't aspire to weaken its control over economy and they did little to set mechanisms of demand and supply in order to provide people for necessary commodities. However, the Fair boosted foreign trade and it at least gave people hope that there would be changes in future. There can be lots of arguments pro and contra if the government really tried to meet people's needs but different measures taken by socialist regime to provide for a channel between citizens' demands and producers shows that the regime had been trying to find a compromise between planned decision-making, official ideology and people's growing consuming needs or at least to make a vision of finding a compromise. What was explicit is that the image of the fair still remained a beautiful dream of a future prosperity the of East German population. 


\section{References}

1. Betts P. The Twilight of the Idols: East German Memory and Material Culture // The Journal of Modern History. Chicago: The University of Chicago Press, September 2000. Vol. 72, No. 3. P. 731-765.

2. CIA-RDP80-00809A000700160061-5 / FOIA ERR. - 08.09.2011. URL: https://www.cia.gov/library/readingroom/ document/cia-rdp80-00809a000700160061-5 (Accessed: 15.05.2019).

3. CIA-RDP80-00810A005900120001-6 / FOIA ERR. - 12.02.2008. URL: https://www.cia.gov/library/readingroom/ document/cia-rdp80-00810a005900120001-6 (Accessed: 27.05.2019).

4. CIA-RDP80-00810A007100860005-7 / FOIA ERR. - 17.11.2008. URL: https://www.cia.gov/library/readingroom/ document/cia-rdp80-00810a007100860005-7 (Accessed: 27.05.2019).

5. CIA-RDP82-00457R001500270006-4 / FOIA ERR. - 21.03.2001. URL: https://www.cia.gov/library/readingroom/ document/cia-rdp82-00457r001500270006-4.

6. Kaminsky A. Illustrierte Konsumgeschichte der DDR. - Erfurt: Landeszentrale für politische Bildung Thüringen, 1999. $100 \mathrm{p}$

7. Meet the GDR. Dresden: Verlag Zeit im Bild, 1966. $92 \mathrm{p}$.

8. Otto A. Sozialistische Öffentlichkeitsarbeit in der DDR: Eine empirische Studie am Fallbeispiel des Leipziger Messeamts. Wiesbaden: Springer VS, 2015. $240 \mathrm{p}$.

9. Pence K. «A World in Miniature»: The Leipzig Trade Fairs in the 1950s and East German Consumer Citizenship Consuming Germany and the Cold War. Ed. by Crew D. N.Y.: Berg, 2003. P. 21-50.

10. Prior F. The communist foreign trade system. Cambridge, Massachusetts: the M.I.T. Press, 1963. $296 \mathrm{p}$

11. Reid S. The Soviet Pavilion at Brussels '58: Convergence, Conversion, Critical Assimilation, or Transculturation? // CWIHP Working Paper. Ed. By Ostermann C. December 2010. No.62. 67 p. URL: https://wilsoncenter.org/sites/default/files/ WP62_Reid_web_V3sm.pdf (Accessed: 02.06.2019).

12. Schramm M. Konsumgeschichte. URL: https:/www.docupedia.de/images/9/9c/Konsumgeschichte_Version_2.0_ Manuel_Schramm.pdf (Accessed: 31.05.2019).

\section{Информация об авторах}

Крючков Юрий Игоревич - магистр гуманитарного института Северо-Кавказского федерального университета (Ставрополь) / уouyou5@yandex.ru

Крючков Игорь Владимирович - доктор исторических наук, профессор, заведующий кафедрой зарубежной истории, политологии и международных отношений гуманитарного института Северо-Кавказского федерального университета (Ставрополь) / igory5@yandex.ru

\section{Information about the authors}

Kryuchkov Yurii - MA student, Institute of Humanities, North-Caucasus Federal University (Stavropol) / youyou5@ yandex.ru

Kryuchkov Igor - Doctor of History, Professor, Head of Chair of Foreign History, Political Science and International Relations, North-Caucasus Federal University (Stavropol) / igory5@yandex.ru 